\title{
Better Teaching and Learning (BTL) Model on Islamic Religious Education Lessons
}

\author{
Edi Saputra' ${ }^{1}$, Saiful Akhyar Lubis ${ }^{2}$, Adlan 3 \\ DOI: 10.35445/alishlah.v13i2.619
}

\begin{tabular}{l} 
Article Info \\
\hline Keywords: \\
Better Teaching and \\
Learning; \\
Islamic Education; \\
ADDIE Model
\end{tabular}

Kata kunci: Better Teaching and Learning; Pendidikan Agama Islam; Model ADDIE

\begin{abstract}
The purpose of this study is to determine whether the BTL learning paradigm is feasible, legitimate, and effective in Islamic Religious Education sessions. The study population consisted of 48 students in grades VIII A and B at SMPN 7 Medan. This research method combines Research and Development and the ADDIE Model. The study's findings indicate that when compared to the conventional model, the BTL learning model in Islamic Religious Education sessions produces a practical BTL model. Following trials, the BTL learning model for Islamic Religious Education lectures resulted in a valid model and steps. After implementing the BTL learning model in Islamic Religious Education lessons for students in grades VIII A and B of SMPN 7 Medan, it was discovered that the processes from learning to development were beneficial.
\end{abstract}

\begin{abstract}
Abstrak
Penelitian ini bertujuan menjawab permasalahan dari 3 rumusan masalah yang meliputi bagaimana model pembelajaran BTL pada pelajaran Pendidikan Agama Islam yang praktis, valid dan efektif. Populasi penelitian ini adalah kelompok siswa kelas VIII A dan B SMPN 7 Medan yang berjumlah 48 siswa. Metode penelitian ini menggunakan Research and Development dengan Model ADDIE. Hasil penelitian menunjukkan bahwa Model pembelajaran BTL pada pelajaran Pendidikan Agama Islam dengan tahapantahapan yang telah dilalui maka menghasilkan model BTL yang praktis dibandingkan dengan model konvensional. Model pembelajaran BTL pada pelajaran Pendidikan Agama Islam setelah melalui uji coba maka menghasilkan model yang valid, serta langkah-langkah model pembelajaran BTL pada pelajaran Pendidikan Agama Islam siswa-siswi kelas VIII Sekolah Menengah Pertama Negeri Tujuh setelah dilaksanakan ternyata memiliki langkah-langkah yang efektif dari langkah-langkah pembelajaran sebelum pengembangan.
\end{abstract}

${ }^{1}$ Universitas Islam Negeri Sumatera Utara Medan, Sumatera Utara, Indonesia Email: edisaputra2009@gmail.com ${ }^{2}$ Universitas Islam Negeri Sumatera Utara Medan, Sumatera Utara, Indonesia Email: saifulakhyar5@gmail.com 3Universitas Islam Negeri Sumatera Utara Medan, Sumatera Utara, Indonesia Email: adlankadisdikmedan@gmail.com 


\section{INTRODUCTION}

Education is the process of producing a better value and cultural system, among other things, in developing a student's personality, skills, and intellectual development. This harmonises with the 2013 scripbud no. 69 on the curriculum (known today by the term 'k13') states that "education is rooted in the nation's culture for the building up of current national life and for building the basis for a better nation's life in the future." At formal institutions, the learning process is done primarily with the mediation of learning teaching several subjects in the class. One of the subjects that contribute to the early development of personality, skill, and science is the subject of Islamic Religious Education (Salsabila et al., 2021). Islamic Religious Education is a conscious and planned effort in preparing students to recognise, understand, believe, be pious, have a noble character, practice Islamic teachings from the main source of the holy book al-Quran and al-Hadith, through activities of guidance, teaching, training, and education (Hermilia et al., 2021).

As new learning theories emerged, with the democratisation of education, the increasingly sophisticated information and communication technologies, the greater the need for problemsolving and investigative ability, and the more significant and faster the discovery of new theories relating to learning. Such approaches as these, problem-solving (the problem of based learning), cooperative learning, and contextual learning (contextual teaching and learning) are approaches that experts highly encourage to use during the learning process of classes in Indonesia.

Constructivism states that knowledge will form or awaken in the student's mind when he seeks to organise his new experience based on a preexisting cognitive framework in his or her experience in terms of preexisting mental capture (Durbin, 2013). Thus, learning Islamic Religious Education is acquiring knowledge created or performed by the student himself through transforming the student's individual experience. In addition, the importance of problem-solving, especially when students are already at work or while studying other materials, will require changes in the learning process in classes, including junior high school (junior high) throughout Indonesia.

According to the reasoning and example above, the constructive meaning of their mutual learning is that 1) a teacher's exertion in teaching does not always result in positive outcomes for his or her students. Each junior high school student must develop their knowledge in their minds, depending on their pre-existing cognitive framework. As a result, it is only through effort that students will fully comprehend the information. Every teacher must have realised that while such content has been discussed, some students still have not comprehended the material. This demonstrates that a teacher can teach a student effectively while still having all or a few pupils fail to study. 2) Each teacher's assignment is to aid his or her students' knowledge acquisition rather than impart it. Students should be able to acquire and incorporate new experiences into their cognitive frameworks on an active basis. Thus, Islamic Religious Education will be more effective when teachers assist students in identifying and resolving difficulties through the application of relevant learning. 3) To teach effectively, teachers must grasp students' mental models of the world and the reasonings they built and used to support those models. Thus, teachers must be willing to inquire about and monitor their pupils' work. Each student's misstep must serve as input as the design for the next learning phase is refined. 4) Students must construct their understanding of each concept. The teacher's role in teaching is not to "lecture," explain, or make similar efforts to transfer knowledge of Islamic Religious Education to students, but to create situations that assist students in making necessary mental constructions.

Learning is essentially an effort to direct learners into the learning process to achieve the desired learning goal. Learning should take note of the particular condition of the child because they will learn. Learners are distinct individuals from one another, unique in each other. Therefore, learning should note the child's differences so that learning can change a child's condition from ignorance to knowledge, from ignorance to understanding, and from ill-behaved behaviour to good. The actual children's condition, for a long time, was of little interest to the educators. This is shown 
by the attention of some teachers/educators who tend to observe the overall class, not individual or group of children, so individual differences get less attention. Another symptom is seen in the fact that many teachers use the same tend teaching methods each time a class takes place.

The fact that the government has arranged various training on the learning model for teachers. The present learning model paradigm has gone from teacher-centred to student-centred learning. Teachers must attend this for students to understand new learning models that can be applied at school. The study-centred learning developed today has not touched the domain of character. Therefore, needs to be developed a learning model capable of developing student character. One learning model that is believed to change that paradigm is better teaching and learning (BTL). This is the development of better teaching and learning developed by decentralised primary education.

The results of previous research conducted by (Sukaesih \& Pukan, 2015) reviewed the increase in students' process skills. Better Teaching And Learning with character (BTL-K) can grow character, improving enthusiasm, activity, and result learn students (Rusilowati et al., 2012). BTL is also recommended to be applied in the education and training of the teaching profession and can be used as an innovative strategy to improve the quality of the learning process (Sukaesih \& Alimah, 2012). Research by Hansah et al. (2014) determines activities and achievement after applying the Better Teaching and Learning (BTL) process. Then, Yulianti \& Bintari (2013) research developed junior high school students' character and critical thinking ability through learning model better teaching and learning (BTL). The research result that obtained application BTL can be developed character and critical thinking ability although the criteria are medium range. This possibly happens because character and critical ability are the habits that should be trained repeatedly and continuously. Consequently, it needs more research to increase character and critical ability.

This study focus on the BTL learning paradigm is feasible, legitimate, and effective in Islamic Religious Education sessions. This research is essential to do to produce a BTL model that suits the needs of the targeted students

\section{METHODS}

This research technique incorporates both Research and Development and the ADDIE Model. The researchers, in turn, conducted interviews with students from a secondary school and gleaned some information about Islamic religious education subjects from the interviews, including the following: first, students believe that teachers who teach lessons are more likely to use only speech techniques, implying that teachers are preying and recording and thus Second, pupils are never invited to participate fully in the classroom learning process. The facts about Islamic Religious Education learning discovered by researchers in the field motivate researchers to seek out and build a strategy model that can accommodate all of a protege's differences. The learning model proposed was one of active learning.

The selected and used development model is the ADDIE model developed by Reiser and Molleda. The work structure of this model could be illustrated as follows: 


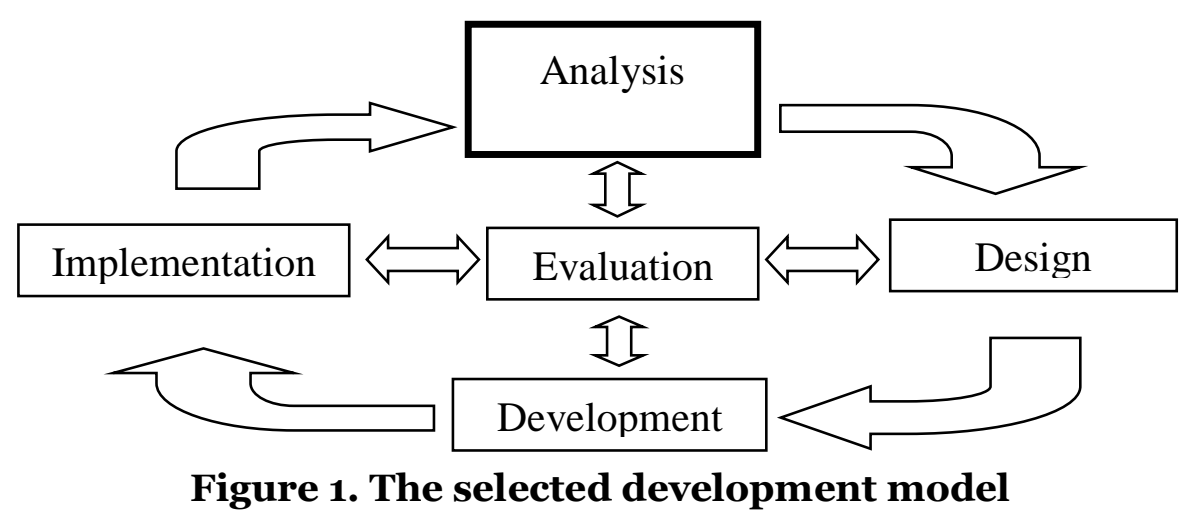

ADDIE models are used in this research because they have several benefits compared with other development models. The intended advantage is more operational, systematic, practical, and more procedural measures so that reasonably relevant is used as one of the essential building codes of learning models. The subsequent use of the foreign term (ADDIE) researchers agreed with a more specific Indonesian term: analysis to analysis, design to design, improvement to development, improvement to application, and revision to evaluation.

\section{FINDINGS AND DISCUSSION}

Research in this study reveals the implementation of model BTL learning by sort card in SMPN 7 Medan terrain.

\section{Analysis Stage}

The analysis step is to develop what material is suitable for students in Islamic Religious Education lessons through needs analysis. The needs analysis refers to the curriculum guidelines that refer to the syllabus and lesson plans for Islamic Religious Education subjects at SMPN I Medan City. Researchers collected data through appropriate instruments related to problems in Islamic Religious Education lessons at SMPN 7 Medan to get good and correct identification results. The researchers then used the data as the basis for designing the development of the BTL model with the sort card method, which was more adaptive and effective by the characteristics of the learning material, students, and learning objectives.

Analysis of problems in the Islamic Religious Education learning process at SMPN 7 Medan was carried out on planning, implementation, evaluation, and learning follow-up. Based on the observations made, several problems were found in the implementation of Islamic Religious Education learning at SMPN 7 Medan, including:

a) Islamic Religious Education learning planning has weaknesses in incompleteness and imperfection of learning tools such as syllabus, lesson plans, teaching materials, and learning media.

b) Implementing Islamic Religious Education learning at SMPN 7 Medan focuses on the teacher centre learning method, the teacher as the centre of learning activities. The implementation of learning so far has been dominated by the lecture method, so that students in the implementation of learning have low motivation.

c) There are also gaps in Islamic Religious Education learning evaluation activities. The teacher rarely assesses every meeting and does not return the results of the work answer sheets or student assignments that have been assessed to be used as feedback for students.

d) In follow-up activities in Islamic Religious Education learning, the teacher does not provide action in an individual or group approach to students with learning difficulties.

After analysing the needs for Islamic Religious Education learning from planning, implementation, evaluation, and follow-up, Islamic Religious Education learning, especially in 
Islamic Religious Education material at SMPN 7 Medan, needs to be arranged learning tools so that learning tools can be arranged learning effectiveness can be achieved.

\section{Design Stage}

The researcher conducted interviews with students from a secondary school (August o6, 2019) and gleaned some information about Islamic religious education subjects from the interviews. The interviews including the following: first, students believe that teachers who teach lessons are more likely to use only speech techniques, implying that teachers are preying and recording. Second, pupils are never invited to participate fully in the classroom learning process. The facts about Islamic Religious Education learning discovered by researchers in the field motivate researchers to seek out and build a strategy model that can accommodate all of a protege's differences. The learning model proposed was one of active learning.

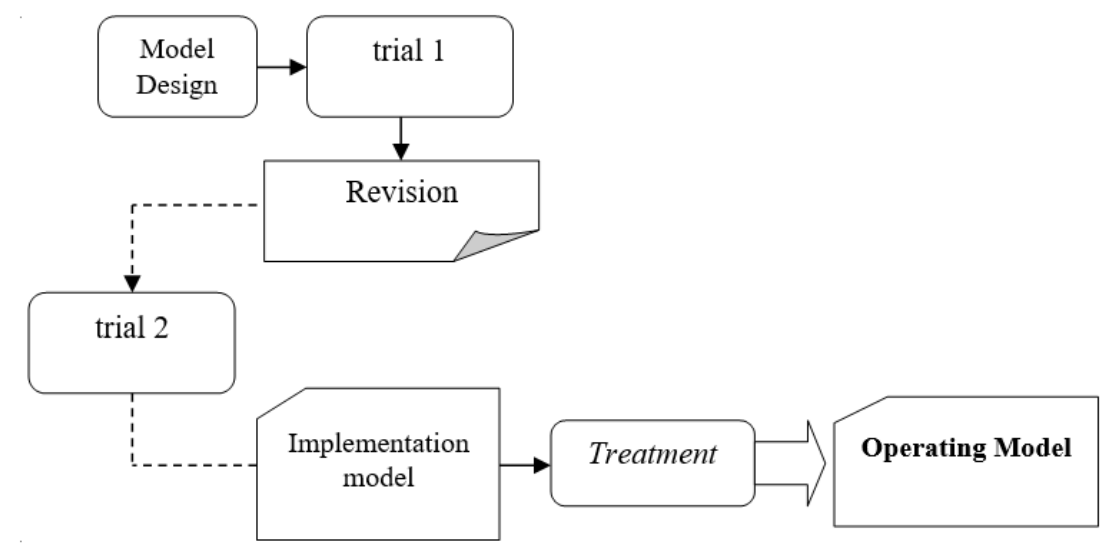

Figure 2. Design stage

\section{Development Stage}

The development stage is the design blueprint into a complete model, ready to be tested in the Islamic Religious Education learning process. To get the results of developing a BTL learning model with a suitable sort card method, the researchers carried out content validation, and construction validation steps developed to improve the weaknesses that still exist in these sections. In this case, validation is carried out through discussion and consultation with the promoter commission, experts, and Islamic Religious Education teaching teachers. The results of the development are then poured into the form of learning tools.

The results of the BTL learning model validation with the sort card method have several assessed aspects. Aspects assessed include theoretical basis, Islamic Religious Education learning objectives, stages of developed learning models, lesson syllabus, lesson plans, learning materials, and evaluation tools. Three experts carried out this assessment/validation with different aspects, namely Education Technology experts, Grammar experts, and Construct and Content experts. The assessment results obtained indicate that the average value is 4.4 . This shows that each validated aspect is in the very valid category (if the mean is $>3.20$. It is categorised as very valid).

Table 1. The results of the validation of the BTL learning model

\begin{tabular}{|c|c|c|c|c|c|c|}
\hline \multirow{2}{*}{ No } & \multirow{2}{*}{ Aspect } & \multicolumn{3}{|c|}{ Score } & \multirow{2}{*}{ Total } & \multirow[t]{2}{*}{ Average } \\
\hline & & V1 & V2 & V3 & & \\
\hline 1 & Theoretical basis & 4 & 4 & 4 & 12 & 4.0 \\
\hline 2 & Material purpose & 4 & 4 & 4 & 12 & 4.0 \\
\hline 3 & $\begin{array}{l}\text { The stages of the developed learning } \\
\text { model }\end{array}$ & 5 & 4 & 4 & 13 & $4 \cdot 3$ \\
\hline
\end{tabular}




\begin{tabular}{|c|c|c|c|c|c|c|}
\hline \multirow{2}{*}{ No } & \multirow{2}{*}{ Aspect } & \multicolumn{3}{|c|}{ Score } & \multirow{2}{*}{ Total } & \multirow[t]{2}{*}{ Average } \\
\hline & & V1 & V2 & V3 & & \\
\hline 4 & Syllabus & 5 & 4 & 5 & 14 & $4 \cdot 7$ \\
\hline $\begin{array}{l}5 \\
6 \\
7\end{array}$ & $\begin{array}{l}\text { Lesson plan } \\
\text { Learning materials } \\
\text { Evaluation tool }\end{array}$ & $\begin{array}{l}5 \\
5 \\
4\end{array}$ & $\begin{array}{l}5 \\
5 \\
4\end{array}$ & $\begin{array}{l}5 \\
5 \\
4\end{array}$ & $\begin{array}{l}15 \\
15 \\
12\end{array}$ & $\begin{array}{l}5.0 \\
5.0 \\
4.0\end{array}$ \\
\hline \multirow{2}{*}{7} & Average & & & & & 4.4 \\
\hline & Intraclass Correlation & \multicolumn{4}{|c|}{$\begin{array}{c}\text { Single Measures } \\
\text { Average Measures }\end{array}$} & $\begin{array}{l}.657^{\mathrm{a}} \\
.852 \\
\end{array}$ \\
\hline
\end{tabular}

After validation by the experts, a product revision was made based on suggestions and input from these experts. A learning model with Islamic Religious Education material was produced with a BTL model approach with the sort card method ready to be tested on a limited basis.

The development stage is also in teacher and student books, so it is ready to be tested in the Islamic Religious Education learning process. To get the results of developing a BTL learning model for teachers and students with a good sort card method, the researchers carried out content validation and construction validation steps that were developed in order to improve the weaknesses that still exist in these sections. In this case, validation is carried out through discussions and consultations with the promoter commission, experts, and Islamic Religious Education teaching teachers.

The validation of teacher and student books with the BTL learning model with the sort card method has several assessed aspects. Aspects assessed include organisation, format, material/content, and language. This assessment/validation was carried out by four experts/experts with different aspects, namely Educational Technology Experts, Grammar Experts, and Construct and Content Experts. All the validators also assess/validate the product as a whole and state it is valid.

\section{Table 2. The results of the validation of teacher and student books with the BTL learning model}

\begin{tabular}{clcc}
\hline No & \multicolumn{1}{c}{ Aspect } & Student's book & Teacher's book \\
\hline 1 & Organization & 4,3 & 4,1 \\
2 & Format & 4,1 & 4,4 \\
3 & Material/content & 3,9 & 4,4 \\
4 & Languange & 4,1 & 4,3 \\
\hline
\end{tabular}

Overall, the teacher's book and the student's book are categorised as very valid based on the assessment of the validator. However, the validator has more important suggestions in revising the teacher's book and student's book to be realised. Suggestions from the validator include: Writing techniques must be improved, the order of the pages should be better, the structure of the material is still not well sorted, and images that are not coloured try not to be included or replaced.

After the teacher and student books were revised according to the validator's suggestions, some validators/assessment teams are re-assessed. However, not all product/model validators are returned because some validators have stated that they are valid. The overall assessment of the teacher's book and student's book can be declared very valid. From the revision results obtained, the following product or can be said to be the second product.

\section{Implementation Stage}

At this stage, the learning system is ready to be used by students. The development of the BTL learning model with the sort card method is carried out. In this case, the model is no longer 
validated but directly applied to the two groups. The first group is a group of students who applied the BTL development model with the sort card method, and the second group was a group of students who applied the conventional method.

The implementation of BTL model development using the sort card method is carried out in the following phases: Phase 1: Initial orientation, Phase 2: Group formation and assignment, Phase 3: Exploration, Phase 4: Learn to become an expert group, Phase 5: Re-Orientation, Phase 6: Group presentation in class, Phase 7: Understanding Check, Phase 8: Reflection and conclusion, and Phase 9: Formative evaluation

\section{Evaluation Stage}

The evaluation stage is carried out on the data from the assessment model applied by the teacher in Islamic Religious Education lessons after attending the lesson by applying the development of the BTL learning model with the sort card method. Based on the research data, the researchers made a description, analysis, and interpretation related to the dimensions of the effectiveness of the model developed by the BTL learning model using the sort card method. The data analysis of the research results is intended to see the condition of the effectiveness of Islamic Religious Education learning seen in classes with the development of BTL learning models and in classes using conventional learning models.

The results of this test can be seen by comparing the scores of students in Islamic Religious Education in the model application class to the scores of students in conventional classes. The average score for Islamic Religious Education students in the model application class is 77.033, while the average score for Islamic Religious Education students in the traditional class is only 67.367. The difference test computation yielded a t-count value of 7.323 with sig 0.000 0.05. It indicates a difference between the Islamic Religious Education value assigned to students in the model application class and the Islamic Religious Education value assigned to students in the conventional class; additionally. This finding indicates that the average Islamic Religious Education value assigned to students in the application class model is greater than the average Islamic Religious Education value assigned to students in the conventional class.

Based on the researchers' interviews with some Islamic Religious Education teachers, they still lack an understanding of the applicable curriculum (2013 curriculum) that merely offers KI and $\mathrm{KD}$, whereas teachers should develop the learning materials. The tendency to lack understanding teachers so that teachers still put students as teacher-centred objects. Learning the teacher performs in the school by relying on their experiences without guiding the drafted plan, causing learning to lose its way and answer. The condition suggests that the practice of learning is conducted without supervision from competent.

As facilitators and mediators, a teacher's assignment is directed on: 1) efforts to provide learning experiences that allow students to be responsible for planning learning activities, learning processes, and the results they obtain; 2) providing several activities that might stimulate a student's curiosity and encourage them to explore and express his or her ideas and communicate them scientifically; 3) providing a study tool that can stimulate students' thinking productively by presenting problematic phenomena and can stimulate students' learning and solving them; And 4) monitoring, evaluating and demonstrating the level of student development, indicating the extent of the student's knowledge in dealing with the phenomena presented (Rambe, 2018).

The learning strategy teachers use in teaching students in the class cannot match the characteristics of the subjects and students if done only by asking and answering questions and discussing being guided (Breslow et al., 2013). The use of such strategies hinders students' active involvement and teachers remain learning centres. The learning strategy that should create a supportive situation and provide students with sufficient opportunities to will and can learn on their promptings to develop its optimum potential (Moser et al., 2017) is even less attention.

A good Islamic Religious Education learning strategy should begin with forming students' attitudes toward learning and then cognitive and skill development. As a good attitude toward study 
grows, students develop their comprehension of the content represented by the teacher. To that aim, organising the learning choices and strategy with a constructive view is one of the keys to successful teachers and subsequent students' learning success.

Effective learning tactics do not end with the repetition of beliefs in pupils but continue until attitudes are manifested later in life by acts or activities. For example, Islamic Religious Education materials will benefit both students and others and thus must be performed. In that sense, a student's belief in the content of Islamic Religious Education must be reinforced through a meaningful learning process (Davidsen, 2010) so that the act's manifestation is likewise significant, both to the student's personal life and to the community's social life.

As a result, an effective technique for teaching pupils is through an active learning model (BTL), which includes group learning strategies with sort cards. Students can speak and interact cordially with one another with this technique, based on mutual comprehension and appreciation for the process of meaning construction via decision-making or mutual agreement. In this regard, the school is positioned as a miniature contest and backdrop for social life in which kids are raised, fostered, and involved in problem-solving. Communication and interaction among students in learning groups that use the critical thinking process might help them improve their cognitive comprehension and development (Dennen, 2013).

According to implementation statistics for Islamic Religious Education, the learning, syllabus, and learning implementation plan; the planning, implementation, and evaluation of the SMPN 7 domains into which the study was done may be considered conventional, unaffected by school qualification or status. That is, the learning activity that teachers engage in while instructing pupils makes no discernible impact. These circumstances are assigned, and a teacher's figure plays a significant role in deciding the quality of the school's processes and learning environments.

Researchers' observations discovered that teachers who deliver lesson materials rely solely on a teacher's handbook (package book) when school learning and media resources are readily available. For example, Islamic Religious Education material can use learning resources such as libraries and the Internet. These learning resources are so helpful in developing students' thinking ability and giving each other that the material development of the Islamic Religious Education will go beyond what the teacher tells it. According to some students in the interviews, their study results with the active study model the teacher has been using have not been good enough. The student feels that he or she cannot learn in a democratic, comfortable, cooperative atmosphere.

The authors' observation of the teacher's learning activities through the use of the original (conventional) model recorded in double the process of studying Islamic Religious Education materials in VIII-a and VIII-b classes at SMPN 7 fields does not seem to be compelling enough, either in the dimensions of worth or in the application of models in the learning process. Performing an active study model (BTL) with a sort card method on studying Islamic Religious Education in the eighth class of the seventh-grade terrain has improved learning effectiveness. Research data analysis aims to see the effectiveness of the study of the Islamic Religious Education seen in classes both with the development of both a BTL learning model and a class using a conventional learning model.

The introduction results are seen from the value of student Islamic Religious Education in the application class with the value of student Islamic Religious Education in the conventional classes. The average application class student Islamic Religious Education value is 77.033, whereas the average value of Islamic Religious Education in conventional classes is only 67.367. The value of the $\mathrm{t}$-count is 7.323 , Which means there is a difference in the value of model student Islamic Religious Education with the value of conventional class student Islamic Religious Education. This result also proves that the average value of model student Islamic Religious Education is higher than that of conventional class student Islamic Religious Education.

Testing their effectiveness and discussions above, the BTL study model with its sort card methods of development is proving more effective than the conventional learning model (before 
development) as described. Researchers realise that there is no perfect learning model because each model has certain advantages and deficiencies depending on the goal.

Implementation of model BTL with measures card on Islamic Religious Education matter in eighth class in junior state seven terrains has been shown to improve learning effectiveness. There is a difference in the student's application of Islamic Religious Education value with the conventional student Islamic Religious Education. It also proves that the average model student's actual class Islamic Religious Education value is higher than the conventional class average. The BTL learning model with this sort of card method has limitations or roughly been used for lessons that are not Islamic Religious Education oriented.

\section{CONCLUSION}

BTL learning model was more practical than the conventional model. After a trial, the BTL learning model in Islamic religious education subjects at SMPN 7 resulted in a valid model. The steps of the BTL learning model turned out to have practical steps from the learning steps before development. The results of this study have implications for a comprehensive study of practical learning to improve the quality of learning, such as strategies or learning steps, teaching materials or materials, learning resources and media, and evaluation of the learning process and results. One of the urgent implications of this research is the strategic and practical role and function of teachers in learning. The study results indicate that the teacher's role and function are needed and cannot be replaced by others, either as initiators, motivators, facilitators, directors, and dynamists and evaluators in learning.

Its competence primarily influences the resource capability of an educator in compelling Islamic Religious Education study, that is, pedagogical competence, professional competence, social competence, and personality competence. As a result, it is expected that more educators will improve and improve their performance through seminar activities, workshops, and so forth. Implementation of BTL study with this sort of card method proves to improve learning effectiveness, especially in Islamic Religious Education material. It would be necessary for the field education service to allocate time and funds in publishing and organising learning models by sort card methods, primarily in Islamic Religious Education material. These active learning model products are not worth anything if they are not getting support from those associated with increased teacher competence in Islamic Religious Education study.

\section{REFERENCES}

Breslow, L., Pritchard, D. ., DeBoer, J., Stump, G. ., Andrew, D., \& Seaton, D. . (2013). Studying learning in the Worldwide Classroom Research into edX's First MOOC. Environmental Psychology and Nonverbal Behavior, 2(4), 250-252. https://doi.org/10.1007/BFo1173772

Davidsen, M. (2010). Integrative Religious Education in Europe. A Study-of-Religions Approach. $\begin{array}{llll}\text { Zeitschrift Für Junge Religionswissenschaft, } & 5(1), & 128-131 .\end{array}$ https://doi.org/10.1163/156852708x373339

Dennen, V. . (2013). Student thought and classroom language: Examining the mechanisms of change in dialogic teaching. Educational Psychologist, 48(2), 813-828.

Dewi, I. ., Poedjiastoeti, S., \& Prahani, B. . (2017). ElSII Learning Model Based Local Wisdom To Improve Students' Problem Solving Skills and Scientific Communication. International Journal of Education and Research, 5(1), 107-118.

Durbin, P. T. (2013). New Waves In Philosophy Of Technology. In Techné: Research in Philosophy and Technology (Vol. 13, Issue 2). https://doi.org/10.5840/techne200913215

Hansah, F., Yulianti, D., \& Sugianto, S. (2014). Pembelajaran Fisika Menggunakan Better Teaching And Learning Berketerampilan Proses Untuk Meningkatkan Aktivitas Belajar Siswa Smp. 2(3), 61-67. https://doi.org/10.15294/upej.v2i3.2932

Hermilia, H., Ahyani, N., \& Yan Putra, A. (2021). The Effect of Creativity and Work Motivation on the Productivity of Islamic Religious Education Teachers. Edunesia: Jurnal Ilmiah Pendidikan, 2(2), 464-473. https://doi.org/10.51276/edu.v2i2.145

Moser, S., Zumbach, J., \& Deibl, I. (2017). The effect of metacognitive training and prompting on 
learning success in simulation-based physics learning. Science Education, 101(6), 944-967. https://doi.org/10.1002/sce.21295

Rambe, R. N. . (2018). Penerapan Strategi Index Card Match Untuk Meningkatkan Hasil Belajar Siswa Pada Mata Pelajaran Bahasa Indonesia. Jurnal Tarbiyah, 25(1). https://doi.org/10.30829/tar.v25i1.237

Rusilowati, A., Hartono, H., \& Supriyadi, S. (2012). Pengembangan Model Pembelajaran Better Teaching and Learning Berkarakter Untuk Membekali Kompetensi Pedagogi Mahasiswa Calon Guru. Jurnal Penelitian Pendidikan Unnes, 29(2), 124710. https://doi.org/10.15294/jpp.v29i2.5649

Salsabila, U. H., Agustin, A., Safira, F., Sari, I., \& Sundawa, A. (2021). Manfaat Teknologi Bagi Mata Pelajaran PAI di Masa Pandemi Covid-19 A . Pendahuluan satu mata pelajaran yang umum terdapat di sekolah negeri dan swasta yang mempunyai Hadist . Dasar Yuridis Dasar pelaksanaan pendidikan agama berasal dari perundang- peganga. Edunesia : Jurnal Ilmiah Pendidikan, 2(1), 125-132. https://doi.org/10.51276/edu.v2i1.93

Sukaesih, S., \& Alimah, S. (2012). Penerapan Praktek Pembelajaran Bermakna Berbasis Better Teaching Learning (Btl) Pada Mata Kuliah Microteaching Untuk Mengembangkan Kompetensi Profesional Calon Guru. Jurnal Penelitian Pendidikan Unnes, 29(2), 124627. https://doi.org/10.15294/jpp.v29i2.5658

Sukaesih, S., \& Pukan, K. K. (2015). Active Learning Based on Better Teaching and Learning (Btl) To Improve Process Skill and Students Study Result. Jurnal Pendidikan IPA Indonesia, 4(1), 9096. https://doi.org/10.15294/jpii.v4i1.3507

Yulianti, D., \& Bintari, S. . (2013). Better Teaching And Learning IPA Untuk Mengembangkan Karakter Dan Kemampuan Berpikir Siswa SMP. Jurnal Penelitian Pendidikan, 30, 23-32. https://doi.org/10.15294/jpp.v30i1.5663 